Journal of Science
http://dergipark.gov.tr/gujs

\title{
In-Vitro Bioactivity Investigation of Sol-Gel Derived Alumina-Bovine Hydroxyapatite (BHA) Composite Powders
}

\author{
Azade YELTEN ${ }^{1}$ (D), Oksan KARAL-YILMAZ ${ }^{(D)}$, Zeynep Puren AKGUNER ${ }^{\text {(D) }}$, Ayça BAL-OZTURK ${ }^{3,4}$ (D), \\ Suat YILMAZ ${ }^{1, *}$ \\ ${ }^{I}$ Istanbul University-Cerrahpasa, Faculty of Engineering, Department of Metallurgical and Materials Engineering, 34320, Avcilar-Istanbul, \\ Turkey \\ ${ }^{2}$ Beykent University, Faculty of Engineering-Architecture, Department of Chemical Engineering, 34398, Ayazaga-Istanbul, Turkey \\ ${ }^{3}$ Istinye University, Faculty of Pharmacy, Department of Analytical Chemistry, 34010, Zeytinburnu-Istanbul, Turkey \\ ${ }^{4}$ Istinye University, Institute of Health Sciences, Department of Stem Cell and Tissue Engineering, 34010, Zeytinburnu-Istanbul, Turkey
}

\section{Highlights}

- Synthesis of the $\mathrm{AlOOH}$ gel via the sol-gel procedure was described in detail.

- Production steps of the AlOOH-bovine hydroxyapatite (BHA) mixtures were explained.

- Preparation of $\mathrm{Al}_{2} \mathrm{O}_{3}$-BHA composite powders was achieved through the heat-treatment process.

- Chemical, microstructural and physical analyses of the composite powders were performed.

- In-vitro bioactivity (MTT assay) characterization of the composite powders suggested great promise.

\section{Article Info}

Received: $18 / 03 / 2019$

Accepted: 28/05/2020

Keywords

Alumina

Bovine Hydroxyapatite

Sol-Gel Method

Biocomposites

In-Vitro Bioactivity

\begin{abstract}
Alumina $\left(\alpha-\mathrm{Al}_{2} \mathrm{O}_{3}\right)$ and hydroxyapatite $\left(\mathrm{HA}, \mathrm{Ca}_{10}\left(\mathrm{PO}_{4}\right)_{6}(\mathrm{OH})_{2}\right)$ are well-known for being clinically successful bioceramic materials. In this work, in-vitro biological characterization of the sol-gel alumina-bovine hydroxyapatite composite powders was realized. Alumina powders were synthesized through the sol-gel process. First, boehmite $(\mathrm{AlOOH})$ sol was prepared utilizing aluminium isopropoxide $\left(\mathrm{Al}_{(}\left(\mathrm{OC}_{3} \mathrm{H}_{7}\right)_{3}, \mathrm{AIP}\right)$ as the starting precursor. Bovine hydroxyapatite (BHA) powders, which can be defined as naturally derived calcium phosphate powders were added as 10, 20, 30, and 50\% wt. of AIP to each AlOOH sol. Homogeneous dispersion of the BHA powders in the $\mathrm{AlOOH}$ sol was managed due to employing Na-alginate as a kind of thickener. Gelation of the $\mathrm{AlOOH}-\mathrm{BHA}$ mixtures was carried out at $110^{\circ} \mathrm{C}$ for $3 \mathrm{~h}$. After drying, AlOOH-BHA mixtures were heat-treated at $1300^{\circ} \mathrm{C}$ for $2 \mathrm{~h}$. Chemical, microstructural, thermal, and physical properties of the precursors/process products were characterized with X-Ray Diffraction (XRD), Fourier Transform Infrared Spectroscopy (FT-IR), X-Ray Fluorescence Spectroscopy (XRF), Differential Thermal Analysis (DTA), and Scanning Electron Microscopy - Energy Dispersive Spectroscopy (SEM-EDS) analyses. Indirect MTT assay was done to evaluate the biocompatibility of the $\mathrm{Al}_{2} \mathrm{O}_{3}$ - $\mathrm{BHA}$ based biocomposite extracts using the $\mathrm{L} 929$ cell line. It is found that all $\mathrm{Al}_{2} \mathrm{O}_{3}-\mathrm{BHA}$ composite extracts with varying doses of $25 \%$ and $50 \%$ had no negative effect on the cell viability. In addition, \% cell viability decreased with the increasing of the extract concentration. It can be concluded that the prepared $\mathrm{Al}_{2} \mathrm{O}_{3}-\mathrm{BHA}$ composites can be a good candidate for biomedical applications.
\end{abstract}

\section{INTRODUCTION}

Bioceramic materials are commonly used for hard tissue replacement and healing purposes. They can be in either ceramic, glass or glass-ceramic form. "Bioceramics" is the general name for the biocompatible ceramics and/or ceramic composite materials that are used in various prostheses and implants. Bioceramic materials can function in orthopedic surgery (vertebrae implants, total hip implants, maxillofacial constructions, etc.) and dental surgery applications thanks to their significant properties like excellent biocompatibility, chemical stability against body fluids such as blood and saliva, high mechanical strength, 
and aesthetical appearance. Specific interactions occur between the tissue and material surfaces, when a bioceramic implant material is placed into the body. These interactions can be categorized in three types depending on the implanted bioceramic material: bioinert, bioactive and bioresorbable. Alumina $\left(\alpha-\mathrm{Al}_{2} \mathrm{O}_{3}\right)$ and hydroxyapatite $\left(\mathrm{HA}, \mathrm{Ca}_{10}\left(\mathrm{PO}_{4}\right)_{6}(\mathrm{OH})_{2}\right)$ are well-known for being clinically successful bioceramics. Despite its high wear and corrosion resistance and high compression strength characteristics, the limited tissue bonding capacity of $\alpha-\mathrm{Al}_{2} \mathrm{O}_{3}$ makes it a bioinert material. Conversely, $\mathrm{HA}$, a bioactive ceramic, is found as crystals in the bone structure and has a superior capability of forming biochemical bonds with the tissues when inserted as an implant [1-3]. HA is a popular biomaterial in orthopedics for its proven biocompatibility and biodegradability. However, HA has a brittle character and its load bearing capacity is low. Chondrocyte loaded HA can be a good graft model to stimulate endochondral ossification. Mineralized cartilaginous tissue is formed when chondrocytes are cultured in combination with HA [4,5]. In this study, the target is to investigate the in-vitro behavior of the alumina-bovine hydroxyapatite (BHA) composite powders, where $\alpha-\mathrm{Al}_{2} \mathrm{O}_{3}$ is predicted to provide strength to the composite structure while $\mathrm{BHA}$ is responsible for the bioactivity.

It is possible to encounter with studies and reports based on synthesis of $\mathrm{Al}_{2} \mathrm{O}_{3}$ - $\mathrm{HA}$ composites and their properties [6-11]. Sol-gel process is ideal to produce high chemical purity powders. It is an efficient and economical way to obtain inorganic and/or organic/inorganic composite solids and advanced ceramic materials. Sol-gel method assures several important advantages such as obtaining nano-sized high purity powders, enabling a homogeneous mixture in molecular level, working at low reaction temperatures, having not hazardous side-effects on human health and environment, and requiring a reasonable experimental setup. These benefits keep sol-gel technique preferred in many applications like high-strength ceramics, conductivity, multi-functional coatings, insulating structures, and also biomaterials [12-18].

Pure and highly porous $\alpha-\mathrm{Al}_{2} \mathrm{O}_{3}$ powders were obtained via the sol-gel process in the experimental studies that our research group previously carried out $[17,18]$. In this work, aluminum isopropoxide (AIP) was used as the metal alkoxide starting material to synthesize pure $\alpha-\mathrm{Al}_{2} \mathrm{O}_{3}$ powders via the sol-gel process [12,1921]. Derivation of the BHA powders was realized from natural sources, i.e. bovine bones $[8,22]$. Investigation the biocompability of the biocomposite powders composed of $\alpha-\mathrm{Al}_{2} \mathrm{O}_{3}$ and BHA bioceramic components was the goal of the current research. Besides the X-Ray Diffraction (XRD), Fourier Transform Infrared Spectroscopy (FT-IR), X-Ray Fluorescence Spectroscopy (XRF), Differential Thermal Analysis (DTA), and Scanning Electron Microscopy - Energy Dispersive Spectroscopy (SEM-EDS) analyses, bioactivity determination tests were also performed. Cytotoxicity of the $\mathrm{Al}_{2} \mathrm{O}_{3}$ - $\mathrm{BHA}$ composite samples was evaluated by conducting Indirect MTT assay on L929 cell line.

\section{MATERIALS AND METHODS}

\subsection{Preparation of the $\mathrm{Al}_{2} \mathrm{O}_{3}$-BHA Composite Powders}

$\mathrm{Al}_{2} \mathrm{O}_{3}$-BHA composite powders were prepared through the following procedure; primarily, $\mathrm{AlOOH}$ (boehmite) sol was produced through the hydrolysis of aluminum isopropoxide $\left(\mathrm{Al}\left(\mathrm{OC}_{3} \mathrm{H}_{7}\right)_{3}, \geq 98 \%\right.$, $\mathrm{AIP}$, Aldrich) precursor. 100 was selected as the molar ratio of distilled water/AIP considering the Yoldas approach [12], i.e. 40 moles of distilled water/0.4 moles of AIP. Hydrolysis is the initial step of the sol-gel procedure, where 0.4 moles of AIP was reacted with distilled water, whose temperature was reached to 90 ${ }^{\circ} \mathrm{C}$ by employing a magnetic stirrer with hot plate. Peptization, the second stage of the sol-gel process, was performed by adding $30 \mathrm{ml}$ of $\mathrm{HCl}$ ( $37 \%$ diluted up to $10 \%$, Merck) in equal periods to the solution while hydrolysis reactions were still continuing. $\mathrm{HCl}$ solution was added to the system to accelerate the hydrolysis reactions. $\mathrm{pH}$ and temperature values of the AIP solution were continuously kept under control during the hydrolysis and peptization steps. $\mathrm{pH}$ of the synthesized $\mathrm{AlOOH}$ sol was recorded as $~ 2.5$ at the end of the hydrolysis and peptization reactions and the sol has a gel-like appearance. Then the AlOOH sol was mixed with the BHA powders derived from a natural source, i.e bovine bones, by Oktar et al [8]. Deproteinizing the fresh bovine bones with $\mathrm{NaOH}$, washing, calcination, and grinding with the mortar grinder are the stages that were respectively realized to obtain the BHA powders $[8,23]$. In order to achieve the $\mathrm{Al}_{2} \mathrm{O}_{3}-\mathrm{BHA}$ composite powders, BHA powders with the amount of 10, 20,30, and 50\% wt. of AIP were added to each $\mathrm{AlOOH}$ sol and mixed for $1 \mathrm{~h}$ utilizing an overhead stirrer. Sodium alginate $\left(\mathrm{NaC}_{6} \mathrm{H}_{7} \mathrm{O}_{6}, \mathrm{Na}\right.$-alg, Aldrich) 
was also added as wt. 1, 2, 3, and 5\% of its own molecular weight to the AlOOH-BHA mixture to overcome the precipitation tendency of the BHA powders and enable partially homogeneous dispersion of them in the $\mathrm{AlOOH}$ sol. AlOOH-BHA mixtures were gelated at $110^{\circ} \mathrm{C}$ for $3 \mathrm{~h}$ to let the $\mathrm{AlOOH}$ phase lose the residual water and alcohol groups in its structure and form a more rigid mixture. Finally, the dried/gelated AlOOH-BHA mixtures were heat-treated at $1300^{\circ} \mathrm{C}$ for $2 \mathrm{~h}$ with $10^{\circ} \mathrm{C} / \mathrm{min}$ heating rate in the Nabertherm LHT 08/17 furnace [17].

1300AH10, 1300AH20, 1300AH30, and 1300AH50 are the codes for the heat-treated composite samples. In these codes, 1300 is the heat-treatment temperature value, A depicts $\alpha-\mathrm{Al}_{2} \mathrm{O}_{3}$, and $\mathrm{H}$ denotes $\mathrm{BHA}$. 10, 20, 30, and 50 present the (wt.\%) amount of BHA that was added to AlOOH. At the last part of the experimental procedure, formation of the cylindrical shaped pellets from the composite powders was executed with a hydraulic manual press. Sintering of the prepared pellets was done at $1300^{\circ} \mathrm{C}$ for $2 \mathrm{~h}$ with $10{ }^{\circ} \mathrm{C} / \mathrm{min}$ heating rate.

\subsection{Characterization of the $\mathrm{Al}_{2} \mathrm{O}_{3}-\mathrm{BHA}$ Composite Powders}

Various characterization studies were performed to analyze the produced $\mathrm{Al}_{2} \mathrm{O}_{3}-\mathrm{BHA}$ powders. $\mathrm{Ca} / \mathrm{P}$ wt. ratio of the BHA powders was identified with the Panalytical Axios Minerals branded XRF. DTA of the Na-alginate was performed with TA SDT Q600 model device by using dry air with a heating rate of 10 ${ }^{\circ} \mathrm{C} / \mathrm{min}$ and gas flow speed of $100 \mathrm{ml} / \mathrm{min}$ conditions. Chemical phase characterization of the heat-treated composite powders was carried out with the Rigaku D/Max-2200/PC model XRD through monochromatic $\mathrm{Cu}-\mathrm{K}_{\alpha}$ radiation $(\lambda=0.154 \mathrm{~nm})$. FT-IR graphs were obtained by benefitting from the Perkin Elmer Precisely Spectrum One device and applying the $\mathrm{K}-\mathrm{Br}$ pellet technique. Microstructure details of the composite powders were observed by employing Jeol JSM 6335F (field emission) SEM. Elements that exist in the imaged areas were discovered with the Inca branded semi-quantitative EDS elemental analysis system that works concurrently with SEM. Determination of the apparent porosity (\%) and bulk density features of the pellet samples were implemented considering the well-known Archimedes' Principle.

\subsection{Biocompatibility Experiments}

\subsubsection{Preparation of $\mathrm{Al}_{2} \mathrm{O}_{3}-\mathrm{BHA}$ Composite Extracts}

$\mathrm{Al}_{2} \mathrm{O}_{3}-\mathrm{BHA}$ composites and $1300 \mathrm{Al}_{2} \mathrm{O}_{3}$ powders were firstly incubated in cell culture medium $(1 \mathrm{~g} / 10 \mathrm{~mL})$ at $37{ }^{\circ} \mathrm{C}$ for $48 \mathrm{~h}$. Then, the undiluted extracts $(100 \%)$ were sterilized by filtrating with $0.22 \mu \mathrm{m}$ syringe filters (Isolab). In order to enable a dose-response relationship, the extracts were serially diluted in complete Dulbecco's Modified Eagle Medium with high glucose (DMEM, Gibco) to obtain with varying doses of $25 \%$ and $50 \%$.

\subsubsection{Cell Culture}

Mouse fibroblast (L929) cell line was used to perform the biocompatibility experiments. The L929 cells were cultured in Low Glucose Dulbecco's modified Eagle's medium (L-DMEM) with high glucose supplemented with $10 \%$ fetal bovine serum (FBS, Invitrogen) and 1\% Penicilin-Streptomycin (Sigma, USA) at $37{ }^{\circ} \mathrm{C}$ with $\mathrm{CO}_{2}$. When the $\mathrm{L} 929$ cells reached $70-80 \%$ confluence, they were separated from the flask with $0.05 \%$ trypsin / 0.02 EDTA solution (Gibco, USA), suspended by DMEM, and centrifuged at $1500 \mathrm{rpm}$ for $5 \mathrm{~min}$. After removal of the supernatant, cells were suspended by DMEM, and counted by thoma slide and seeded into 96-well plates at a density of $5 \times 10^{3}$ cells/well. After allowing attaching overnight, the medium in each well was replaced with $200 \mu \mathrm{L} /$ well of the extraction and standard culture medium as the control group. Then the cells were incubated for $48 \mathrm{~h}$ without changing the cell culture medium. Cells of the 5th passage were used for the experiments. 


\subsubsection{MTT Assay}

In here, biocompatibility of $\mathrm{Al}_{2} \mathrm{O}_{3}$ - $\mathrm{BHA}$ composites extracts with varying doses of 25,50 , and $100 \%$ were investigated. The biocompatibility of the $\mathrm{Al}_{2} \mathrm{O}_{3}$ - $\mathrm{BHA}$ composite powder samples was tested by measuring cell viability with the MTT assay L929 cell line. The MTT (3-(4.5-dimethylthiazol-2-yl)-2.5-diphenyl tetrazolium bromide) assay is one of the most used methods for the detection of sample biocompatibility. In this study, indirect MTT assay was conducted to determine the cytotoxicity of the samples [24]. After 48h, incubation period of the sample extracts with cells, $200 \mu \mathrm{l}$ of DMEM and $20 \mu \mathrm{l}$ of MTT solution (500 $\mu \mathrm{g} / \mathrm{ml}$, diluted with PBS) per well were added, and incubated for a further $4 \mathrm{~h}$ for formazan crystal formation. Then, in order to dissolve formazan crystals, the supernatant was replaced with $200 \mu 1$ of DMSO. After incubation for $20 \mathrm{~min}$. at $37{ }^{\circ} \mathrm{C}$, the supernatant solution was measured at $570 \mathrm{~nm}$ utilizing a microplate reader (BMG Spectroster, Germany). DMEM cell culture medium (without sample extracts) was used as positive control. Viability of cultures exposed to only DMEM cell culture medium was set a $100 \%$ to make a comparison with the responses of the control [25]. The number of replicates was five. Data points were given as mean \pm standard deviation. One-way ANOVA followed by Tukey's test was performed for each group using the GraphPad Prism 6.0 Software.

\section{RESULTS AND DISCUSSION}

$(\mathrm{Ca} / \mathrm{P})$ wt. ratio of the BHA powders used in the composites was calculated as 1.98 depending on the results of the XRF analysis, where wt. Ca\% and wt. P\% were found as 39.12 and 19.74 , respectively. As the natural HA powders employed in the production process were derived from the bovine bones, $(\mathrm{Ca} / \mathrm{P}) \mathrm{wt}$. ratio of the BHA powders (1.98) is different but close to that of the stoichiometric HA (2.15). XRD results (Figure 1) demonstrate that the composite powders include $\alpha-\mathrm{Al}_{2} \mathrm{O}_{3}$ and $\mathrm{CaP}$ based phases, i.e. $\mathrm{HA}$ and and tricalcium phosphate $\left(\mathrm{Ca}_{3}\left(\mathrm{PO}_{4}\right)_{2}\right.$, Whitlockite, $\beta$-tri-calcium phosphate, $\beta$-TCP). Since Na-alginate, which was used for thickhening the $\mathrm{AlOOH}-\mathrm{BHA}$ mixtures is an organic polysaccharide [26,27], it disappeared from the system between $\sim 200{ }^{\circ} \mathrm{C}$ and $\sim 600{ }^{\circ} \mathrm{C}$ according to the DTA curve (Figure 2). Therefore, it did not exist in the XRD results of the heat-treated composite powders. The PDF numbers of the detected phases were determined as 74-1081 and 99-0036 for $\alpha-\mathrm{Al}_{2} \mathrm{O}_{3}, 76-0694$ and 89-6438 for HA, and 09-0169 for $\beta$-TCP. HA and $\beta$-TCP belong to the same compound family, hence it was a difficult issue to separate these two phases. Although the diffraction angle values of the strongest peaks of HA $\left(31.715^{\circ}\right.$ for $\left.(211)\right)$ and $\beta$-TCP $\left(31.026^{\circ}\right.$ for $\left.(0210)\right)$ phases are very close to each other and some of the main peaks may be overlapped and/or shifted, there are distinctive peaks that helped us to detect HA and $\beta$-TCP and remark them on the XRD graphs. It is assumed that the $\beta$-TCP phase appeared in the composite powders due to the high heat-treatment temperature $\left(1300^{\circ} \mathrm{C}\right)$, which influenced the stability of the HA phase and caused its decomposition to $\beta$-TCP. However at least $1300{ }^{\circ} \mathrm{C}$ is required for the transformation of unstable $(\gamma-\delta-\theta-)$ $\mathrm{Al}_{2} \mathrm{O}_{3}$ phases to the stable $\alpha-\mathrm{Al}_{2} \mathrm{O}_{3}$ phase $[12,17]$. Thus, $1300{ }^{\circ} \mathrm{C}$ was chosen and applied as the heattreatment temperature of the $\mathrm{AlOOH}-\mathrm{BHA}$ gel mixtures.

Decomposition reaction of the HA phase realized through the oxyapatite $\left(\mathrm{Ca}_{10}\left(\mathrm{PO}_{4}\right)_{6} \mathrm{O}\right)$ phase. As $\mathrm{HA}$ dehydrates at $\sim 1300{ }^{\circ} \mathrm{C}$, oxyapatite forms. Aqeuous environment conditions enhance the trasformation tendency of oxyapatite to the HA phase. TCP and tetracalcium phosphate (TTCP) formed after the decomposition of oxyapatite but TTCP did not appear in the presented composite samples [28, 29]. It is interpreted that the decomposition process of HA was partially completed so that HA and TCP phases were identified together in the structure instead of TTCP and TCP [6]. As it is well known from the literature, $\alpha$ $\mathrm{Al}_{2} \mathrm{O}_{3}$, HA and TCP phases take place in the bioceramics class and are intensely used in biomedical applications in terms of prostheses and implants. Moreover $\beta$-TCP shows bioresorbable interactions with the body tissues and it may increase the biochemical bond forming capacity of the intended $\mathrm{Al}_{2} \mathrm{O}_{3}-\mathrm{BHA}$ biocomposites [1,2]. Therefore, this triple composite material is thought to be advantegous for the biomedical studies. 


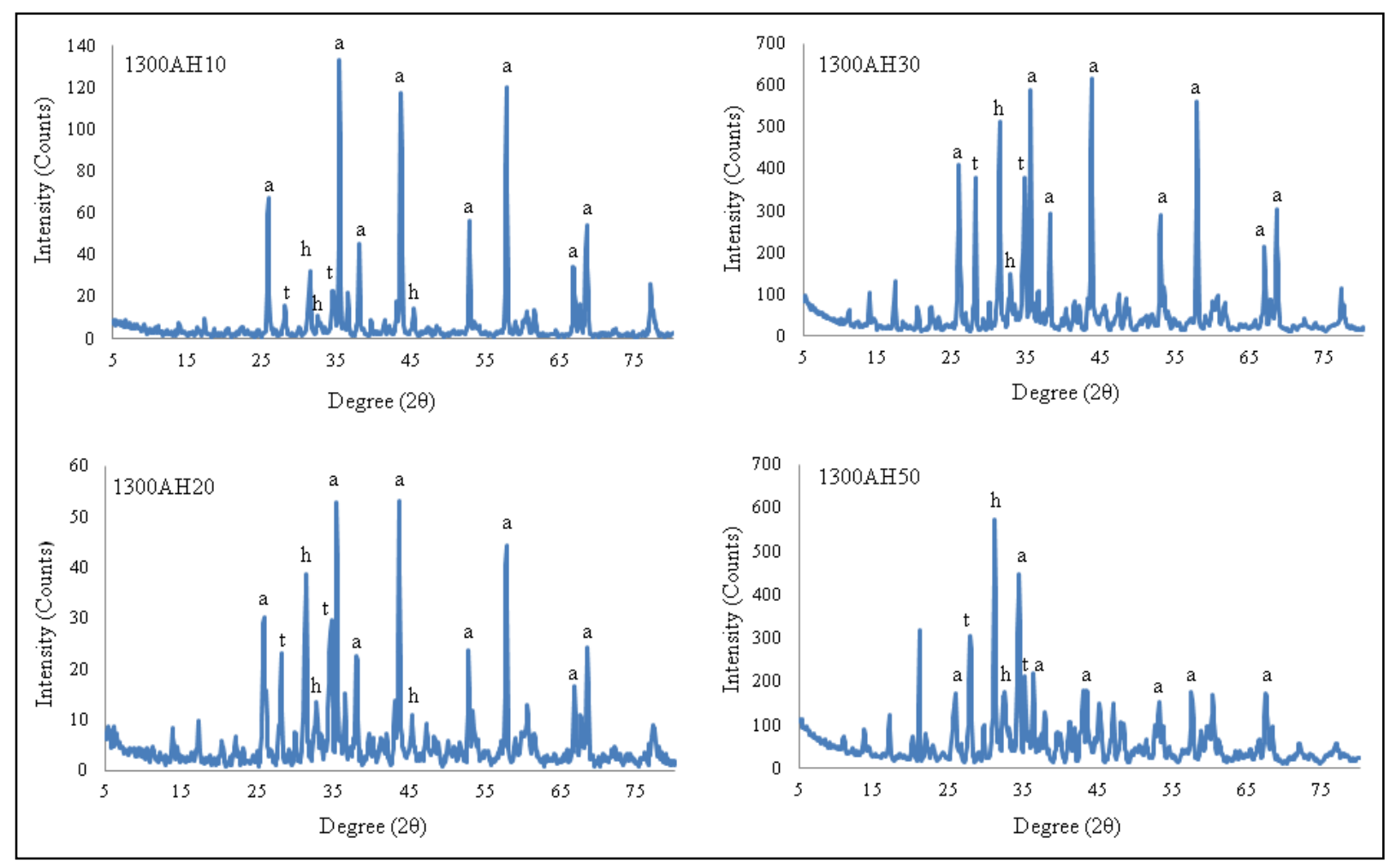

Figure 1. XRD results of the $\mathrm{Al}_{2} \mathrm{O}_{3}-\mathrm{BHA}$ composite powder samples ( $a$ : $\left.\alpha-\mathrm{Al}_{2} \mathrm{O}_{3}, h: H A, t: \beta-T C P\right)$

FT-IR spectra of pure BHA and pure $\alpha-\mathrm{Al}_{2} \mathrm{O}_{3}$ phases are given in Figure 3a and Figure 3b, respectively, while Figure 4 exhibits the FT-IR analyses of the composite powders. Figure 4 includes the main bands that refer to the $\mathrm{P}-\mathrm{O}, \mathrm{CO}_{3}{ }^{-2}$ and $\mathrm{Al}-\mathrm{O}$ vibrations as can be also recognized from the FT-IR graphs of the pure BHA and $\alpha-\mathrm{Al}_{2} \mathrm{O}_{3}$ phases. The peak chain between $1120 \mathrm{~cm}^{-1}$ and $947 \mathrm{~cm}^{-1}$ indicated as (1) on the spectra was attributed to the $\mathrm{P}-\mathrm{O}$ stretching vibrations of the $\mathrm{PO}_{4}^{-3}$ ions in $\mathrm{HA}$. The band marked as (2) between $835 \mathrm{~cm}^{-1}$ and $702 \mathrm{~cm}^{-1}$ represents the vibrations of the $\mathrm{CO}_{3}^{-2}$ ions, which may arouse from the other ions that replaced in the HA structure due to the utilization of natural sources, i.e. bovine bones. The characteristic band noted as (3) between $602 \mathrm{~cm}^{-1}$ and $587 \mathrm{~cm}^{-1}$ was referred to the P-O bending vibrations of $\mathrm{PO}_{4}{ }^{3-}$ ions in the $\mathrm{HA}$ structure. Al-O bond vibrations that are signed as (4) on the spectra were detected at $602-603 \mathrm{~cm}^{-1}$ and $503-468 \mathrm{~cm}^{-1}[17,30-33]$.

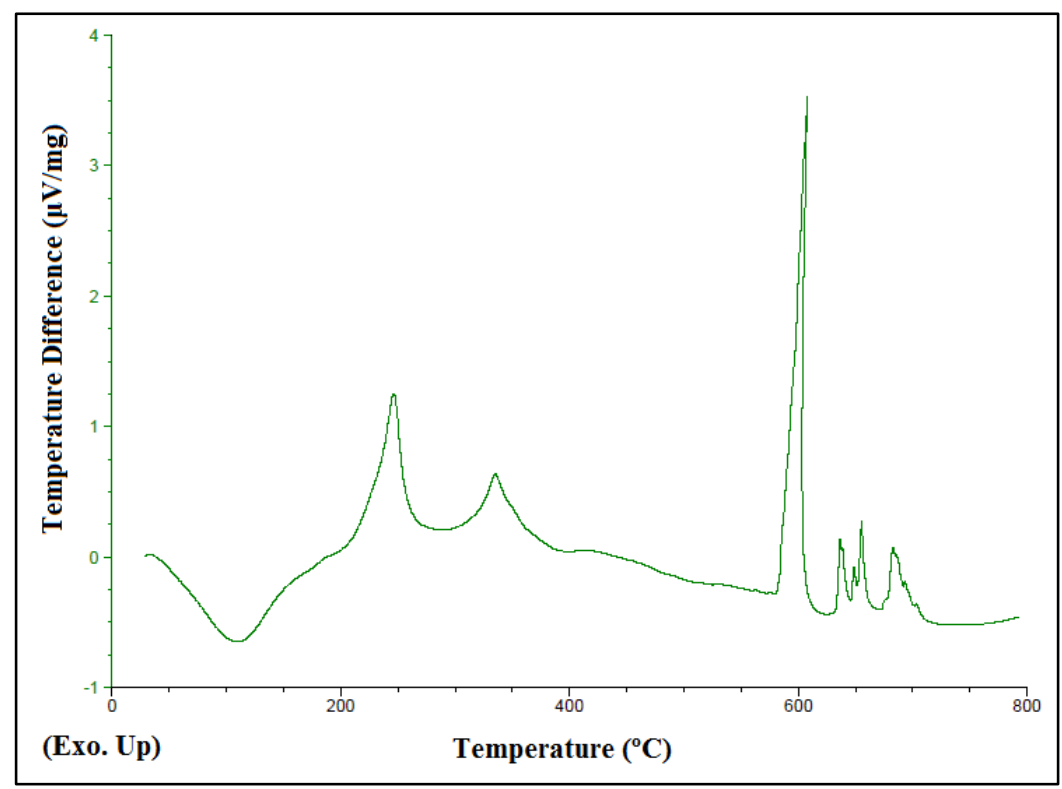

Figure 2. DTA curve of Na-alginate 


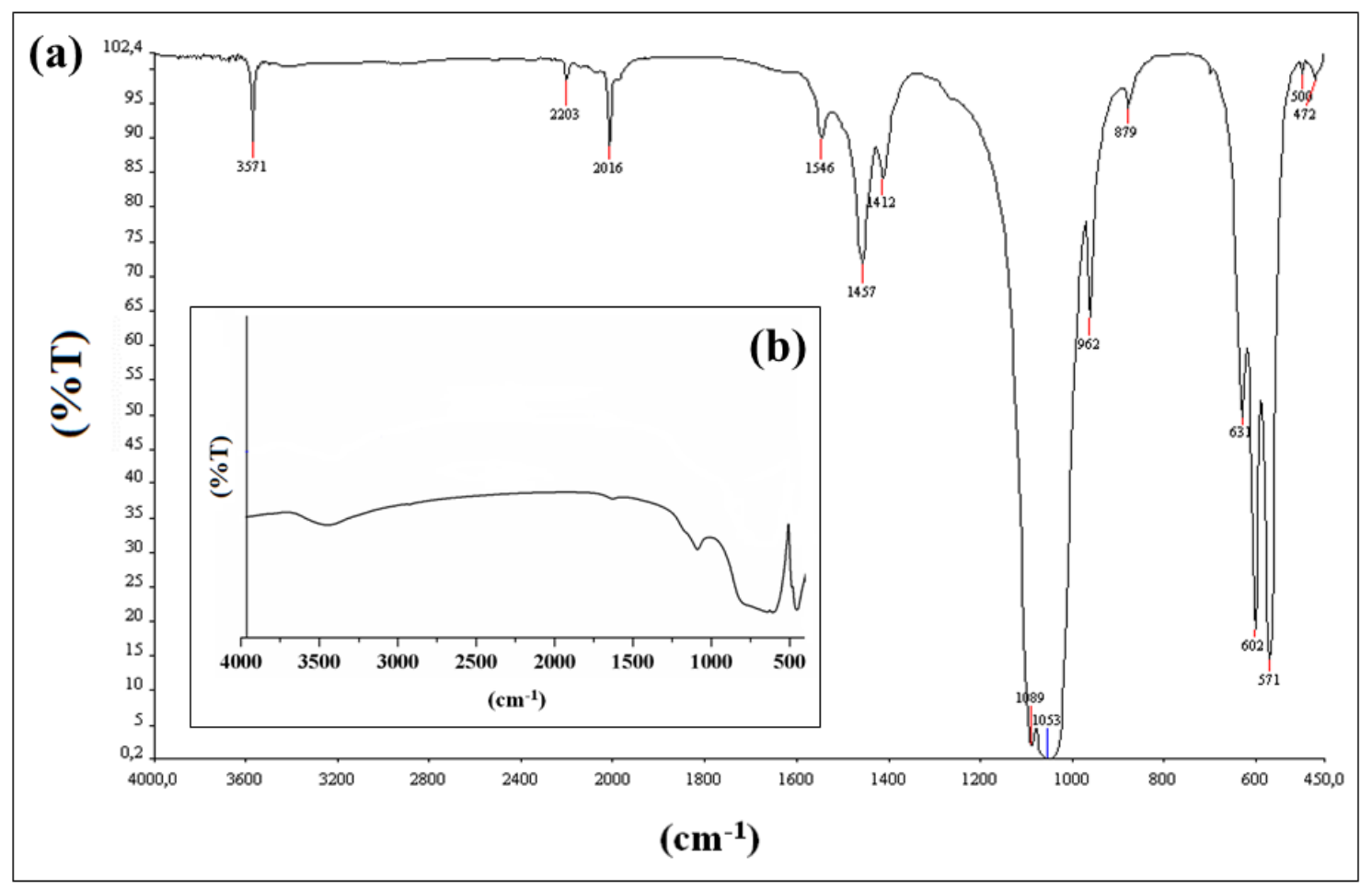

Figure 3. FT-IR analyses of (a) pure BHA and (b) pure sol-gel derived $\alpha-\mathrm{Al}_{2} \mathrm{O}_{3}$

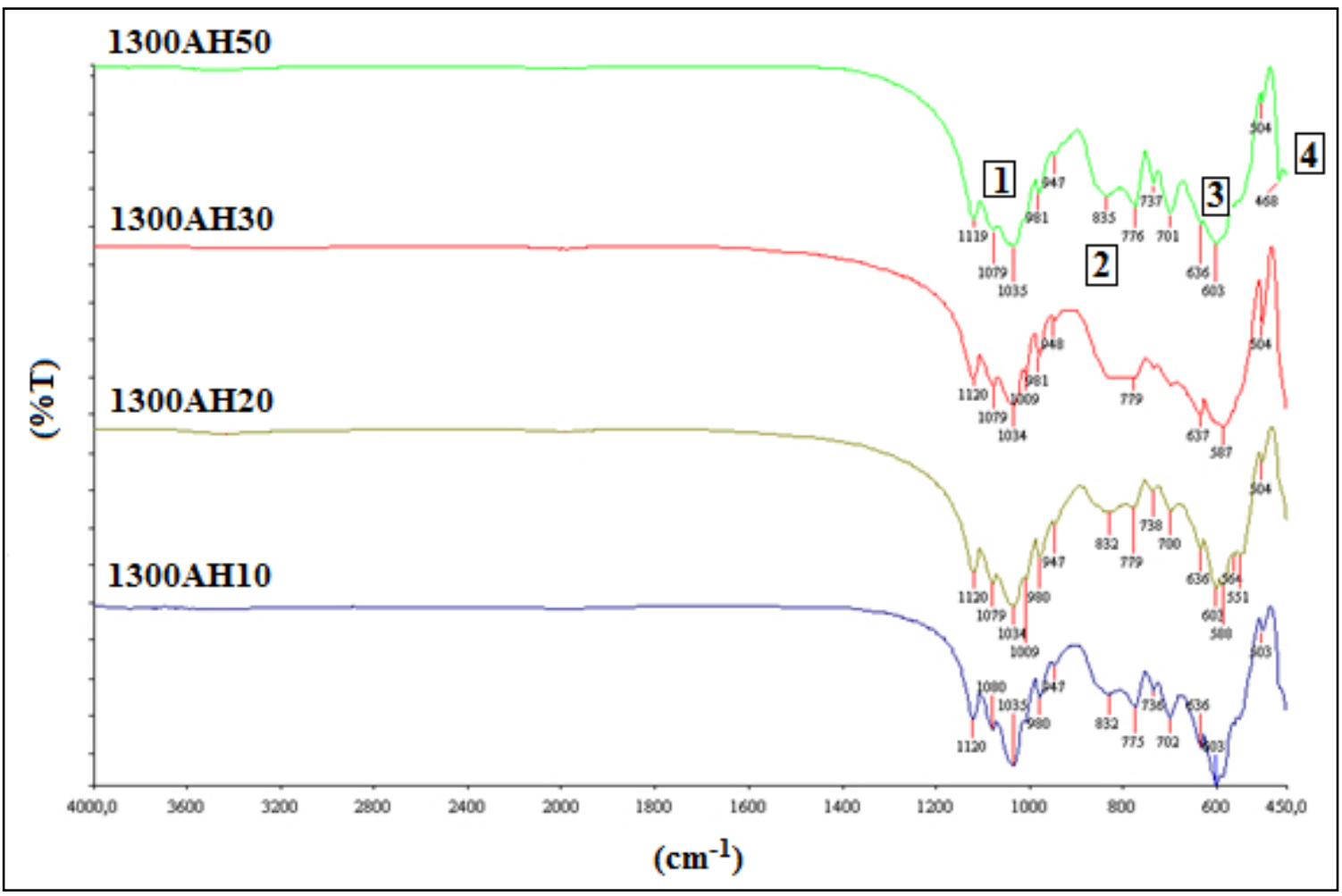

Figure 4. FT-IR analyses of the $\mathrm{Al}_{2} \mathrm{O}_{3}-\mathrm{BHA}$ composite powders

SEM images (Figure 5) nicely demonstrate the highly porous structure of the composite powders. CaP based phases and the $\alpha-\mathrm{Al}_{2} \mathrm{O}_{3}$ phase can be clearly seperated from each other. EDS analyses (Figure 6) helped us to confirm these phases. Besides, the $\sim(\mathrm{Ca} / \mathrm{P})$ molar ratios were found out through the EDS scannings from random regions of each composite powder sample and presented in Table 1. It is noticed that as the wt.\% BHA amount in the composites increased, the $(\mathrm{Ca} / \mathrm{P})$ molar ratio values approached to 1.67 , i.e. the stoichiometric $(\mathrm{Ca} / \mathrm{P})$ molar ratio of the HA phase. However, the $\mathrm{CaP}$ based component in the 
composite system is naturally derived $\mathrm{BHA}$ and as stated previously, BHA partially decomposed to the TCP phase as a result of sintering the $\mathrm{Al}_{2} \mathrm{O}_{3}$ - $\mathrm{BHA}$ composites at $1300{ }^{\circ} \mathrm{C}$. These facts are assumed to be influential on the lower $\sim(\mathrm{Ca} / \mathrm{P})$ molar ratio values of the composite samples with the lower $\mathrm{BHA}$ content.

The needle-like shaped particles belong to the $\alpha-\mathrm{Al}_{2} \mathrm{O}_{3}$ phase while $\mathrm{HA}$ has a spongy structure. It is possible to notice that there are no well-developed neck formations between the particles of different phases owing to the $\mathrm{OH}$ removal from $\mathrm{AlOOH}$ that occurred while $\mathrm{AlOOH}$ was transforming to the stable $\alpha-\mathrm{Al}_{2} \mathrm{O}_{3}$. Such porous structures are also encountered in the researches reported by Bartonickova et al. [6] and Sakka et al. [34] who studied the $\mathrm{HA}-\mathrm{Al}_{2} \mathrm{O}_{3}$ composites and $\beta-\mathrm{TCP}-\mathrm{Al}_{2} \mathrm{O}_{3}$ composites, respectively. Pores are favorable sites for transmitting the necessary nutrition and body fluids to the other parts of the biomaterial. By this way, pores enable better material-tissue interactions and accelerate the healing process. Hence porosity becomes a crucial point for the composite powders and yields the usage of the material to other potential areas such as filling materials or tissue engineering scaffolds, etc. Average apparent porosity (\%) values were measured by using 5 pellets for each composite sample group and found as $38.29 \%$ for 1300AH10, $43.43 \%$ for $1300 \mathrm{AH} 20,43.33 \%$ for $1300 \mathrm{AH} 30$, and $39 \%$ for $1300 \mathrm{AH} 50$.
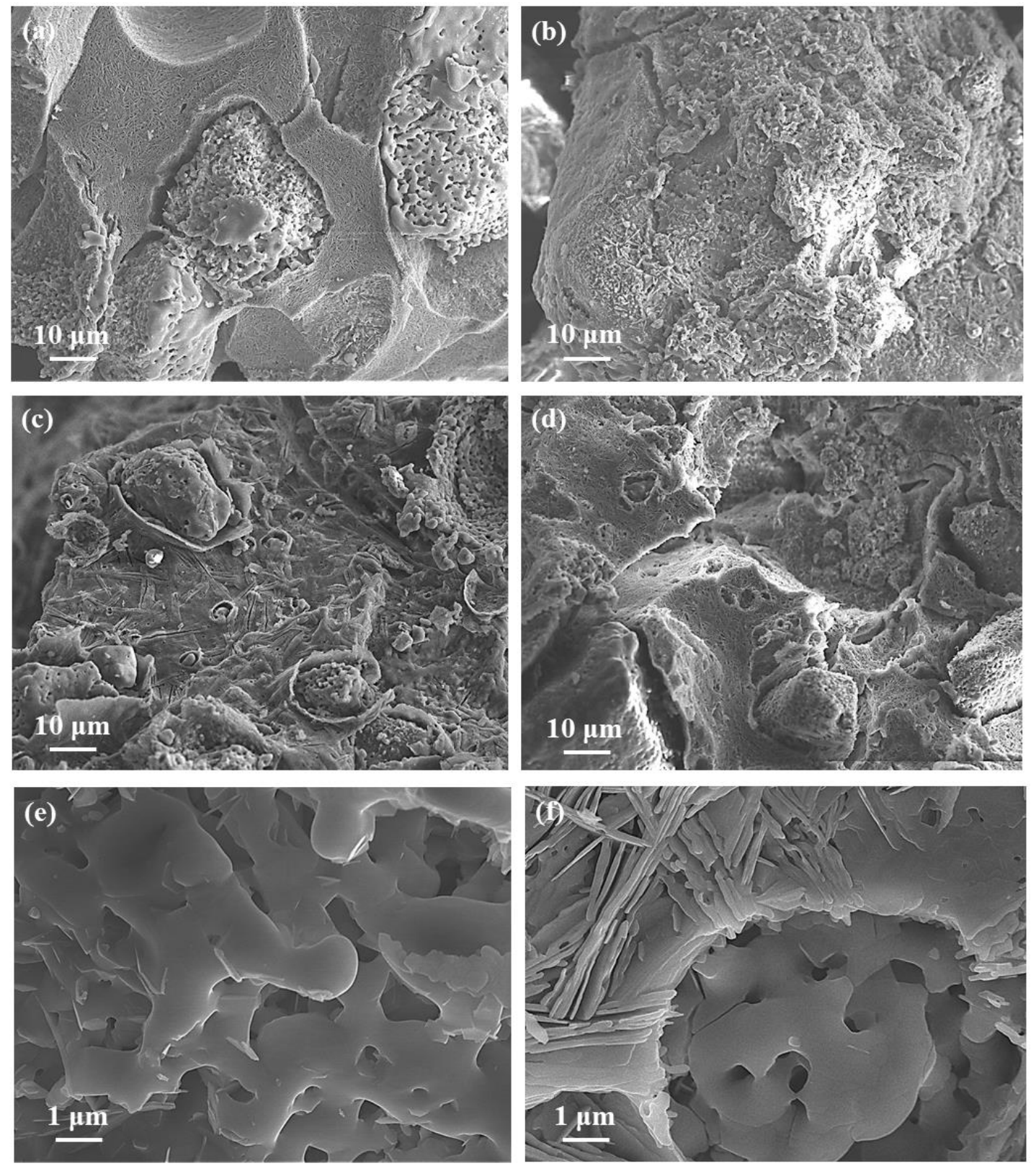

Figure 5. SEM micrographs of (a) 1300AH1O - (b) 1300AH2O - (c) 1300AH30 - (d) 1300AH50 (x500), and (e) 1300AH2O - (f) 1300AH50 (x5000) powder samples 


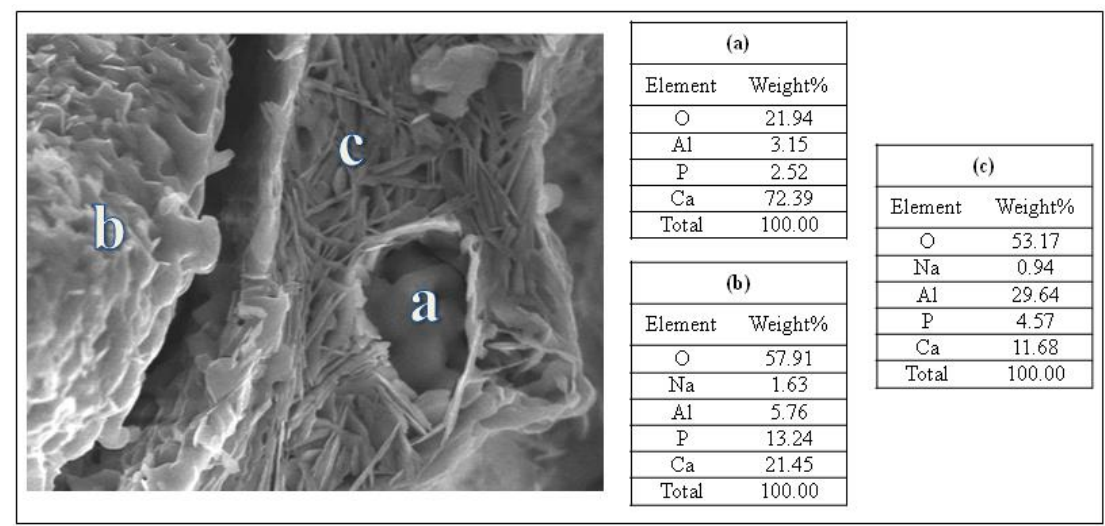

Figure 6. EDS analysis of the 1300AH50 powder sample

Table 1. $\sim(C a / P)$ molar ratios of the composite powders

\begin{tabular}{|l|l|}
\hline Sample Code & $\sim(\mathrm{Ca} / \mathrm{P})$ Molar Ratio (EDS) \\
\hline $1300 \mathrm{AH} 10$ & 1.30 \\
\hline $1300 \mathrm{AH} 20$ & 1.41 \\
\hline $1300 \mathrm{AH} 30$ & 1.52 \\
\hline 1300AH50 & 1.61 \\
\hline
\end{tabular}

Figure 7 shows cell viability results according to the effect of treatment with $\mathrm{Al}_{2} \mathrm{O}_{3}$-BHA composite extracts with varying doses of 25,50 , and $100 \%$. It is found that all $\mathrm{Al}_{2} \mathrm{O}_{3}-\mathrm{BHA}$ composite extracts with varying doses of $25 \%$ and $50 \%$ had no negative effect on the cell viability. As known, $\alpha-\mathrm{Al}_{2} \mathrm{O}_{3}$ has been extensively applied as reinforcing component for HA owing to enhancing especially the mechanical properties of HA and making it cost-effective. In addition, $\alpha-\mathrm{Al}_{2} \mathrm{O}_{3}$ has considerable advantages such as great biocompatibility in its composites [35]. Liu et al. [36] presented a study on graphene-reinforced $\mathrm{Al}_{2} \mathrm{O}_{3}$ nanocomposites. They found that graphene- $\mathrm{Al}_{2} \mathrm{O}_{3}$ composites showed superior biomedical properties. Beyzay et al. [37] examined the cytotoxicity of the $\alpha-\mathrm{Al}_{2} \mathrm{O}_{3}$ on macrophages. Cytotoxicity was observed at higher concentrations $(\geq 1000 \mu \mathrm{g} / \mathrm{ml})$ as cell viability reduced to $75 \%$. Interestingly, the important result is that $1300 \mathrm{AH} 20$ extracts $100 \%$ exhibit statistically higher cell viability in comparison to $1300 \mathrm{Al}_{2} \mathrm{O}_{3} \cdot \mathrm{Cell}$ viabilities of $1300 \mathrm{AH} 20$ extracts concentrations of $100 \%, 50 \%$, and $25 \%$ of culture were $103.4 \pm 18.4 \%$, $112.2 \pm 12.4 \%$, and $141.5 \pm 12.3 \%$, respectively. Furthermore, it can be understood that the \% cell viability of all samples was dose-dependent, which decreased with the increasing of the extract concentration. These findings are compatible with literature [36,38]. The lower HA addition amount resulted in the higher cell viability due to presence of less and smaller pores as also expressed by Song et al. [39]. Although all samples displayed cell viability, it is assumed that the pore size played a significant role in the degree of it. As a matter of fact, it can be concluded that the prepared samples, especially 1300AH20, have a great cytocompatibility, which make $\mathrm{Al}_{2} \mathrm{O}_{3}$ - $\mathrm{BHA}$ composites suitable to be used in biomedical applications.

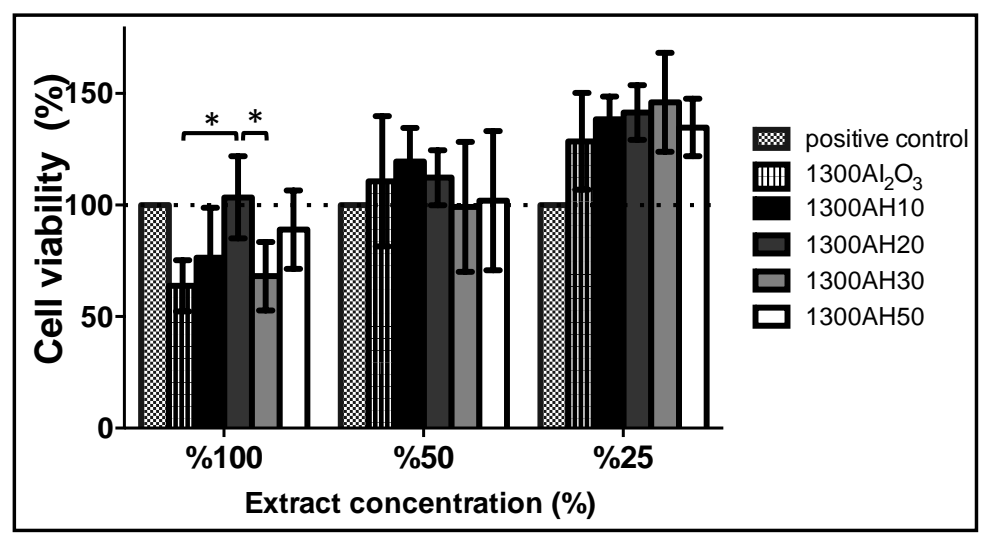

Figure 7. The effect of treatment with $\mathrm{Al}_{2} \mathrm{O}_{3}$-BHA composites extracts with varying doses of 25,50 , and $100 \%$ on cell viability of L929 fibroblast cells assessed by MTT. Data points were presented as mean \pm $S D(* p<0.05 n=5)$ 


\section{CONCLUSION}

Porous composite powders that comprise $\alpha-\mathrm{Al}_{2} \mathrm{O}_{3}, \mathrm{HA}$ and TCP phases were produced by mixing the sol-gel derived $\mathrm{AlOOH}$ sol with the BHA powders obtained from the bovine bones. Chemical phase analyses exhibited the existence of the aforementioned bioceramic phases together in the structure. FT-IR analyses indicated the characteristic vibrations of P-O, $\mathrm{CO}_{3}^{-2}$ and Al-O bands. SEM-EDS characterization studies showed that the $\mathrm{CaP}$ based phases and $\alpha-\mathrm{Al}_{2} \mathrm{O}_{3}$ did not form necks between each other and loosely located so that a highly porous structure occurred, which may be beneficial for several biomedical demands. The biocompatibility of the $\mathrm{Al}_{2} \mathrm{O}_{3}$-BHA composite powder samples was tested by Indirect MTT assay on L929 cell line. All results underline the good biocompatibility of all $\mathrm{Al}_{2} \mathrm{O}_{3}-\mathrm{BHA}$ composite extracts with varying doses of 25 and $50 \%$. Moreover, 1300AH20 extracts $100 \%$ exhibit statistically higher cell viability in comparison to $1300 \mathrm{Al}_{2} \mathrm{O}_{3}$. In the light of all these results, it can be deduced that $\mathrm{Al}_{2} \mathrm{O}_{3}-\mathrm{BHA}$ composites have considerable potential for biomedical applications.

\section{ACKNOWLEDGEMENT}

This work was supported by Scientific Research Project Coordination Unit of Istanbul University [grant number 4201].

\section{CONFLICTS OF INTEREST}

No conflict of interest was declared by the authors.

\section{REFERENCES}

[1] Ratner, B.D., Hoffman, A.S., Schoen, F.J., Lemons, J.E. (eds.), "Biomaterials Science: An Introduction to Materials in Medicine", 2nd ed., Elsevier Academic Press, New York-London, (2004).

[2] Ramakrishna, S., Huang, Z.M., Kumar, G.V., Batchelor, A.W., Mayer, J., "An Introduction to Biocomposites Series on Biomaterials and Bioengineering Vol.1", Imperial College Press, London, (2004).

[3] Chakraborty, J., Basu, D., "Bioceramics-a new era", Transactions of the Indian Ceramic Society, 64(4): 171-192, (2005).

[4] Iyoda, K., Miura, T., Nogami, H., "Repair of bone defect with cultured chondrocytes bound to HA", Clinical Orthopaedics and Related Research, 288: 287-293, (1993).

[5] Van Susante, J.L., Buma, P., Homminga, G.N., Van Den Berg, W.B., Veth, R.P., "Chondrocyte-seeded hydroxyapatite for repair of large articular cartilage defects: A pilot study in the goat", Biomaterials, 19(24): 2367-2374, (1998).

[6] Bartonickova, E., Vojtisek, J., Tkacz, J., Porizka, J., Masilko, J., Moncekova, M., Parizek, L., "Porous HA/alumina composites intended for bone-tissue engineering", Materials and Technology, 51(4): 631636, (2017).

[7] Tayyebi, S., Mirjalili, F., Samadi, H., Nemati, A., "Review of synthesis and properties of hydroxyapatite/alumina nano composite powder", Chemistry Journal, 5(2): 20-28, (2015).

[8] Oktar, F.N., Agathopoulos, S., Ozyegin, L.S., Gunduz, O., Demirkol, N., Bozkurt, Y., and Salman, S., "Mechanical properties of bovine hydroxyapatite (BHA) composites doped with $\mathrm{SiO}_{2}, \mathrm{MgO}, \mathrm{Al}_{2} \mathrm{O}_{3}$ and $\mathrm{ZrO}_{2}$ ", Journal of Materials Science: Materials in Medicine, 18: 2137-2143, (2007).

[9] Evis, Z., Doremus, R.H., "Coatings of hydroxyapatite-nanosize alpha alumina composites on Ti-6Al4V”, Materials Letters, 59: 3824-3827, (2005). 
[10] Sivaperumal, V.R., Mani, R., Nachiappan, M.S., Arumugam, K., "Direct hydrothermal synthesis of hydroxyapatite/alumina nanocomposite", Materials Characterization, 134: 416-421, (2017).

[11] Gupta, A., Tripathi, G., Lahiri, D., Balani, K., "Compression molded ultra high molecular weight polyethylene-hydroxyapatite-aluminum oxide-carbon nanotube hybrid composites for hard tissue replacement”, Journal of Materials Science \& Technology, 29(6): 514-522, (2013).

[12] Yoldas, B.E., "Alumina sol preparation from alkoxides", American Ceramic Society Bulletin, 54(3): 289-290, (1975).

[13] Wright, J.D., Sommerdijk, N.A.J.M., "Sol-Gel Materials Chemistry and Applications Advanced Chemistry Texts", CRC Press, Boca Raton, (2001).

[14] Gvishi, R., "Fast sol-gel technology: from fabrication to applications", Journal of Sol-Gel Science and Technology, 50: 241-253, (2009).

[15] Mackenzie, J.D., "Sol-gel research-achievements since 1981 and prospects for the future", Journal of Sol-Gel Science and Technology, 26: 23-27, (2003).

[16] Belleville, P., "Functional coatings", Comptes Rendus Chimie, 13: 97-105, (2010).

[17] Yelten, A., "Properties and characterization of alumina-bovine hydroxyapatite (BHA) composites produced by sol-gel method", MSc. Thesis, Istanbul University Institute of Graduate Studies in Science and Engineering, Istanbul, (2010).

[18] Yelten, A., Yilmaz, S., Oktar, F.N., "Sol-gel derived alumina-hydroxyapatite-tricalcium phosphate porous composite powders", Ceramics International, 38(4): 2659-2665, (2012).

[19] Dressler, M., Nofz, M., Neumann, R.S., Dorfel, I., Griepentrog, M., "Sol-gel derived alumina layers on nickel base superalloy inconel-718 (IN-718)", Thin Solid Films, 517: 786-792, (2008).

[20] Jing, C., Zhao, X., Zhang, Y., Sol-gel fabrication of compact, crack- free alumina film, Materials Research Bulletin, 42: 600-608, (2007).

[21] Nofz, M., Dorfel, I., Sojref, R., "Microstructure of sol-gel derived corundum containing coatings", Thin Solid Films, 515: 7145-7154, (2007).

[22] Jaber, H.L., Hammood, A.S., and Parvin, N., "Synthesis and characterization of hydroxyapatite powder from natural Camelus bone", Journal of the Australian Ceramic Society, 54: 1-10, (2018).

[23] Kalkandelen, C., Gunduz, O., Akan, A., Oktar, F.N., "Part 1: Clinoptilolite-alumina-hydroxyapatite composites for biomedical engineering", Journal of the Australian Ceramic Society, 53: 91-99, (2017).

[24] Alavarse, A.C., Oliveira Silva, F.W., Colque, J.T., Silva, V.M., Prieto, T., Venancio, E.C., Bonvent, J.J., "Tetracycline hydrochloride-loaded electrospun nanofibers mats based on PVA and chitosan for wound dressing", Materials Science and Engineering C, 77: 271-281, (2017).

[25] Srivastava, G.K., Alonso-Alonso, M. L., Fernandez-Bueno, I., Garcia-Gutierrez, M. T., Rull, F., Medina, J., Pastor, J.C., "Comparison between direct contact and extract exposure methods for PFO cytotoxicity evaluation”, Scientific Reports, 8(1): 1-9, (2018).

[26] Tian, X.Y., Li, M.G., Cao, N., Li, J.W., Chen, X.B., "Characterization of the flow behavior of alginate/hydroxyapatite mixtures for tissue scaffold fabrication”, Biofabrication, 1(4): 1-8, (2009). 
[27] Akhondi, H., Nassaj, E.T., Gilan, A.T., "Gelcasting of alumina-zirconia-yttria nanocomposites with Na-alginate system”, Journal of Alloys and Compounds, 484: 452-457, (2009).

[28] Liao, C.J., Lin, F.H., Chen, K.S., Sun, J.S., "Thermal decomposition and reconstitution of hydroxyapatite in air atmosphere", Biomaterials, 20: 1807-1813, (1999).

[29] Gross, K.A., Gross, V., Berndt, C.C., "Thermal analysis of amorphous phases in hydroxyapatite coatings", Journal of the American Ceramic Society, 81(1): 106-112, (1998).

[30] Abidi, S.S.A., Murtaza Q., "Synthesis and characterization of nano-hydroxyapatite powder using wet chemical precipitation reaction", Journal of Materials Science \& Technology, 30(4): 307-310, (2014).

[31] Kumar, R., Prakash, K.H., Cheang, P., "Temperature driven morphological changes of chemically precipitated hydroxyapatite nanoparticles", Langmuir, 20: 5196-5200, (2004).

[32] Ramesh, S., Aw, K.L., Tolouei, R., Amiriyan, M., Tan, C.Y., Hamdi, M., Purbolaksono, J., Hassan, M.A., Teng, W.D., "Sintering properties of hydroxyapatite powders prepared using different methods", Ceramics International, 39(1): 111-119, (2013).

[33] Chandrasekar, A., Sagadevan, S., Dakshnamoorthy, A., "Synthesis and characterization of nanohydroxyapatite (n-HAP) using the wet chemical technique", International Journal of Physical Sciences, 8(32): 1639-1645, (2013).

[34] Sakka, S., Ben Ayed, F., Bouaziz, J., "Mechanical properties of tricalcium phosphate-alumina composites", IOP Conference Series: Materials Science and Engineering, 28: 012028, (2012).

[35] Pazarlioglu, S., Salman, S. "Effect of lanthanum oxide additive on the sinterability, physical/mechanical, and bioactivity properties of hydroxyapatite-alpha alumina composite", Journal of the Australian Ceramic Society, 55(4): 1195-1209, (2019).

[36] Liu, J., Yang, Y., Hassanin, H., Jumbu, N., Deng, S., Zuo, Q., Jiang, K. "Graphene-alumina nanocomposites with improved mechanical properties for biomedical applications", ACS Applied Materials \& Interfaces, 8(4): 2607-2616, (2016).

[37] Beyzay, F., Hosseini, A. Z., Soudi, S. "Alpha alumina nanoparticle conjugation to cysteine peptidase A and B: an efficient method for autophagy induction", Avicenna Journal of Medical Biotechnology, 9(2): 71, (2017).

[38] Li, Z. H., Wu, J. M., Huang, S. J., Guan, J., Zhang, X. Z. "Strontium hydroxyapatite synthesis, characterization and cell cytotoxicity", Advanced Materials Research, 160: 117-122, (2011).

[39] Song, Y., Ju, Y., Song, G., Morita, Y., "In vitro proliferation and osteogenic differentiation of mesenchymal stem cells on nanoporous alumina", International Journal of Nanomedicine, 8: 27452756, (2013). 